Investigation of the Cytotoxicity of Fig, Lemon, Olive, and Turnip Exosomes on MCF-7 Cells

Oğuzhan KARAOSMANOĞLU

Department of Biology, Kamil Özdağ Faculty of Science, Karamanoğlu Mehmetbey University, 70200, Karaman, Turkey http://orcid.org/0000-0003-2028-7339

$\bowtie$ : karaosmanoglu@kmu.edu.tr

\begin{abstract}
With their nano-sized structure, exosomes are involved in a wide variety of cellular processes such as genetic information flow, immune system modulations, intercellular communication, and pathophysiological changes. The use of exosomes are exponentially growing particularly in the areas of identification of biomarkers, development of nanocarriers for effective drug delivery, and vaccine production. In recent years, edible plant derived exosomes gained much interest with their strong antimicrobial activities, modulatory activities on the intestinal stem cells, and the anticancer activities.

In this study, the cytotoxic effects of fig, lemon, olive and turnip derived exosomes were investigated through the neutral red uptake assay. It was observed that $100 \mu \mathrm{g} / \mathrm{mL}$ protein containing lemon and turnip derived exosomes inhibited the cell proliferation significantly, on the other hand, fig and olive derived exosomes did not alter the proliferation of MCF- 7 cells. Since the results for the cytotoxic activity of turnip exosomes are original in this research, it was found worthy to emphasis the utility of turnip exosomes for the development of new anticancer agents or new drug delivery nanocarriers.
\end{abstract}

\title{
İncir, Limon, Zeytin ve Turp Ekzozomlarının MCF-7 Hücrelerinde Sitotoksik Etkisinin Araştırılması
}

\section{ÖZET}

Nano-boyutlu yapılarıyla ekzozomlar genetik bilgi akışı, immun sistem düzenlenmesi ve patofizyolojik değişiklikler gibi çok çeşitli hücresel süreçlere dahil olurlar. Ekzozomların, özellikle biyoişaret tanımlanması, etkin ilaç dağıtımı için nanotaşıyıcıların geliştirilmesi ve aşı üretilmesi alanlarında kullanımları hızla artmaktadır. Son yllarda yenilebilir bitkilerden türevlenen ekzozomlar yüksek antimikrobiyal etkileri, bağırsak kök hücreleri üzerinde düzenleyici etkileri ve antikanser etkileriyle ilgi çekmektedir.

Bu çalışmada incir, limon, zetin ve turp türevli ekzozomların sitotoksik etkileri nötral kırmızısı alım testiyle araştırılmıştır. Protein miktarı $100 \mu \mathrm{g} / \mathrm{mL}$ olan limon ve turp ekzozomlarının hücre çoğalmasını engellediği gözlenirken incir ve zeytin türevli ekzozomların MCF-7 çoğalmasını etkilemediği görülmüştür. Turp ekzozomlarının sitotoksistik aktivitesi sonuçları, bu araştırmada orijinal olduğu için, yeni antikanser ajanlarının veya yeni ilaç dağıtım nanotaşıyıcılarının geliştirilmesi için turp ekzozomları kullanımına vurgu yapmanın değerli olabileceği düşünülmüştür

To Cite : Karaosmanoğlu O 2019. Investigation of The Cytotoxicity of Fig, Lemon, Olive, and Turnip Exosomes on MCF-7 Cells KSU J. Agric Nat 22(Suppl 2): 382-387. DOI: 10.18016/ksutarimdoga.v22i49454.589845

\section{INTRODUCTION}

Exosomes are endocytic vesicles of late endosomes released as multivesicular bodies. After three decades of dismissing exosomes as a disposal mechanism of cellular waste molecules, researchers have been uncovering the functions of these nanoscale-sized (poses maximum of $100 \mathrm{~nm}$ diameter) extracellular vesicles. Recent publications suggest exosome-
Research Article

$\begin{array}{ll}\text { Article History } & \\ \text { Received } & : 10.07 .2019 \\ \text { Accepted } & : 23.08 .2019\end{array}$

\section{Keywords \\ Exosomes \\ Cytotoxicity \\ MCF-7}

Turnip

\section{Makale Tarihçesi \\ Geliş Tarihi : 10.07 .2019 \\ Kabul Tarihi : 23.08 .2019}

\author{
Anahtar Kelimeler \\ Ekzozomlar \\ Sitotoksisite \\ MCF-7
}

Turnip mediated intercellular transfer of genetic information with the shuttling of DNA, mRNAs, miRNAs, and lncRNAs (Dragomir et al., 2018; Deatherage and Cookson, 2012; Nagarajah, 2016; van Niel et al., 2018). In physiological conditions, exosomes have involved in coagulation, inflammation, cellular homeostasis (Boriachek et al., 2018), immune surveillance (Schorey and Bhatnagar, 2008), fetal survival in pregnancy (Mincheva-Nilsson and Baranov, 2010), and 
neuroprotection (Xin et al., 2013). In pathological conditions, exosomes have included in pre-metastatic niche formation (Hoshino et al., 2015), promotion of angiogenesis (Mineo et al., 2012), metastasis (Min et al., 2018), and extension of neurodegenerative diseases (Pant et al., 2012). Exosomes have both beneficial and detrimental effects on the immune system, such as having anti-tumor effects and inducing immune evasion ( $\mathrm{Li}$ et al., 2006). By reporting the cellular status instantly and easily achievable from various body fluids, exosomes are considered to be an attractive pool of biomarkers in miscellaneous diseases from cancer (Karaosmanoğlu et al., 2018) to Alzheimer (Ma et al., 2018). In addition, with the proven of antitumor and immune stimulatory effects of exosomes by clinical trials, their utilitization in vaccine production has been investigated in recent decades (Escudier et al., 2005). Moreover, exosomes are considered to be effective nanocarriers for drug delivery with their nonimmunogenic, biocompatible and highly stable biological properties (Kibria et al., 2018).

Exosomes are also secreted by plant cells. During fungal and bacterial infections exosomes containing antimicrobial compounds and immune defence-related proteins are accumulated on the regions of being attacked, next, transfer the antimicrobial agents to the invading pathogen (An et al., 2006; Böhlenius et al., 2010; Meyer et al., 2009). In addition, to immune defence, exosomes released from edible plants (carrot, ginger, grapefruit and grape) have been shown to induce the expression of antioxidant, antiinflammation cytokine-related genes in recipient intestinal macrophages and stem cells ( $\mathrm{Mu}$ et al., 2014). Paralelly, grapefruits derived exosomes are shown to functional in the intestine system (B. Wang et al., 2014). Moreover, the ability of grapefruit exosomes to prevent the oral mucositis that is associated with the chemoradiation treatment of head and neck cancer has been shown in a clinical trial (NCT01668849). Besides, grapefruit-derived nanovectors have been observed to be useful for delivering therapeutic agents to inflammatory tumor sites (Wang et al., 2015). Not only grapefruit-derived exosomes but also ginger-derived exosomes are well studied in the literature. In a study, the prophylactic effects of ginger-derived exosomes against alcoholinduced liver damage have been reported (Zhuang et al., 2015). Finally, there is a recent study, conducted with exosomes from 11 edible fruits and vegetables (blueberry, coconut, ginger, grapefruit, Hami melon, kiwifruit, orange, pea, pear, soybean, and tomato) demonstrating the association of exosomal miRNAs with the inflammatory response and cancer-related pathways (Xiao et al., 2018).

Since edible plant derived exosomes have the potential of being used for cancer therapy, the present study conducted to evaluate the cytotoxic effects of exosomes isolated from fig, lemon, olive and turnip which were grown by local Turkish farmers.

\section{MATERIAL METHOD}

Differantial Ultracentrifugation Mediated Exosome Isolation

All fresh fruits are purchased at their season from a local bazaar in Eskişehir (Turkey) then washed thoroughly three times with tap water to remove dirt and dust particles. Seconder wash was performed by using phosphate buffered saline (PBS) for the elimination of contaminating ions and elements in the tap water. For the extraction of lemon juice, hand squeezing was used. For the extraction of olive and turnip juices, $100 \mathrm{~g}$ pieces were weighted, sliced then homogenized with $100 \mathrm{~mL}$ PBS in a mixer. For the extraction of fig juices, $100 \mathrm{~g}$ pieces were weighted, sliced then homogenized with $500 \mathrm{~mL}$ PBS in a mixer. The collected juices from all samples were filtered through a clean muslin cloth and subjected to sequential centrifugation consisting of at $1200 \times \mathrm{g}$ for $20 \mathrm{~min}, 3000 \times \mathrm{g}$ for $20 \mathrm{~min}$, and $10000 \times \mathrm{g}$ for $60 \mathrm{~min}$ at $4{ }^{\circ} \mathrm{C}$ in a Heraeus biofuge centrifuge (Stratos, Thermo, USA), to remove the cellular debris and particles. Using aseptic techniques from this step, supernatant was filtered through a $0.2-\mu \mathrm{m}$ filter (Minisart, Sartorius, Germany) then centrifuged at $150000 \times \mathrm{g}$ for $120 \mathrm{~min}$ at $4{ }^{\circ} \mathrm{C}$ in an $\mathrm{LE}-80 \mathrm{~K}$ ultracentrifuge (Beckman Coulter, Palo Alto, CA, USA) using Type 45 Ti Rotor (Beckman Coulter, Palo Alto, CA, USA) to obtain exosomes. Isolated exosomes were resuspended in $1 \mathrm{~mL}$ sterile PBS and pooled in a new ultracentrifuge tube. Final ultracentrifugation at $150000 \times \mathrm{g}$ for $120 \mathrm{~min}$ at $4{ }^{\circ} \mathrm{C}$ was implemented to pellet the concentrated exosomes.

\section{Exosome Preparation}

The concentrations of exosomes were determined by analyzing protein contents in a fluorescence-based quantitation device (Qubit 2, Thermo, USA). Briefly, ten volumes of exosome suspension in PBS was mixed with a volume of 10x RIPA buffer. Next, the protein content of the mixture was determined with Qubit protein assay kit (Thermo) according to the directions of the manufacturer. The protein contents of the stock exosome pellets are equalized to $1 \mathrm{mg} / \mathrm{mL}$ by diluting in sterile PBS. Then the exosomes were aliquoted and stored at $-80^{\circ} \mathrm{C}$

\section{Cell Culture}

MCF-7 human breast adenocarcinoma cells (ATCC, HTB-22) obtained from Prof. Dr Tansu Koparal (Eskişehir Technical University, Eskisehir, Turkey) was cultured in exosome-depleted Dulbecco's modified Eagle's medium (exofree-DMEM) as previously reported (Théry et al., 2006). Briefly, DMEM (Sigma- 
Aldrich, USA) was supplemented with $20 \%$ fetal bovine serum (FBS) then centrifuged at $100000 \times \mathrm{g}$ in the LE-80 K ultracentrifuge (Beckman Coulter, Palo Alto, CA, USA) using Type 45 Ti Rotor (Beckman Coulter, Palo Alto, CA, USA) for overnight at $4^{\circ} \mathrm{C}$. The supernatant was filtered through a $0.2-\mu \mathrm{m}$ filter (Minisart, Sartorius, Germany) to a sterile bottle. Processed DMEM which contains 20\% FBS was used to prepare the $10 \%$ FBS (Gibco, USA) and 1\% penicillin (100 U/mL)-streptomycin $(100 \mu \mathrm{g} / \mathrm{mL})$. Cells were incubated at $37^{\circ} \mathrm{C}$ in a humidified atmosphere containing $5 \% \mathrm{CO}_{2}$.

\section{Cellular Morphology and Cytotoxicity Assessment}

The cytotoxic effects of isolated exosomes were evaluated with neutral red uptake assay as formerly specified (Karaosmanoğlu et al., 2018). Briefly, cells were separated from the culture flasks by treatment of $0.25 \%$ trypsin/EDTA (Invitrogen) and plated a 96-well culture plate (Thermo Scientific, Germany) with the concentration of $1 \times 10^{4}$ cell/200 $\mu \mathrm{L}$ DMEM. Following overnight incubation, cells were treated with 100 $\mu \mathrm{g} / \mathrm{mL}$ protein containing exosomes and further incubated for $72 \mathrm{~h}$. Since $20 \mu \mathrm{g} / \mathrm{mL}$ nanovesicle containing lemon exosomes was reported to significantly inhibit the proliferation of tumor cells (Raimondo et al., 2015), the cytotoxicity of lemon exosomes was used as a positive control for the evaluation of the cytotoxicity of fig, turnip and olive exosomes. After morphology was evaluated by an inverted microscope (Olympus, BX 50, Center Valley, PA, USA). Next, DMEM containing $50 \mathrm{\mu g} / \mathrm{mL}$ neutral red dye was applied to cells further incubation continued for $3 \mathrm{~h}$. The dye medium was then poured, and cells was washed with PBS. Next, dye extraction solution consisting of acetic acid-water-ethanol in water (1:49:50) was added to each well. After plates were incubated for $15 \mathrm{~min}$ at room temperature with shaking on a GFL 3012 shaker (Gesellschaft für Labortechnik mbH, Burgwedel, Germany). Finally, absorbance values originated from the viable cells was measured by ELx 808 Ultra Microplate Reader (Biotek, USA) equipped with a $540 \mathrm{~nm}$ filter. The viability was evaluated based on a comparison with untreated cells. The $\mathrm{IC}_{50}$ values were calculated by linear regression using Microsoft Excel and presented as a table.

\section{Statistical Analysis}

The experiments were implemented with three independent biological replicates. Graphing and statistical analyses and were executed with GraphPad (GraphPad Prism 6, San Diego, CA, USA). One-way ANOVA with Dunnet post hoc test was used for variance analyses, and $p$-values less than 0.05 were assigned as statistically significant.

\section{RESULTS}

\section{Cellular Morphology}

MCF- 7 cells treated with $100 \mu \mathrm{g} / \mathrm{mL}$ protein containing fig, lemon, olive, and turnip exosomes for $72 \mathrm{~h}$ were photographed by an inverted microscope. As it can be seen from images in Figure 1, control cells were healthy and at a satisfactory concentration for evaluating the exosome-mediated growth alterations of MCF-7 cells.

\section{Control}

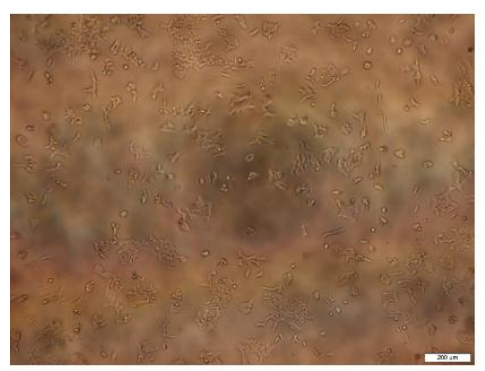

Fig

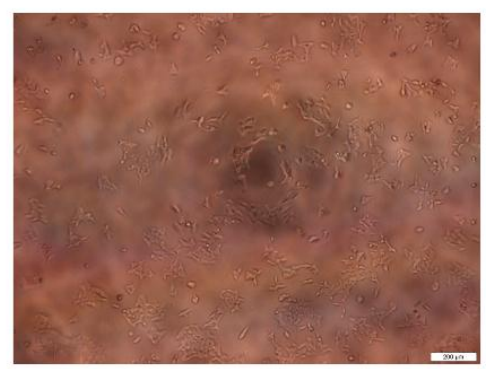

Lemon

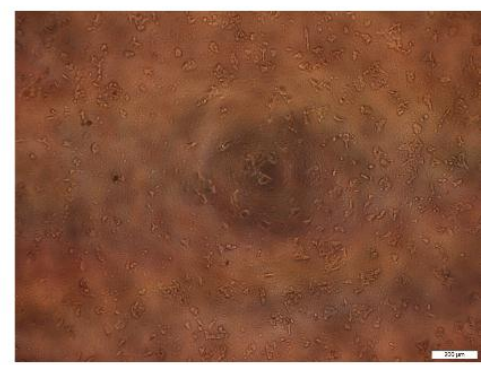

Olive Turnip
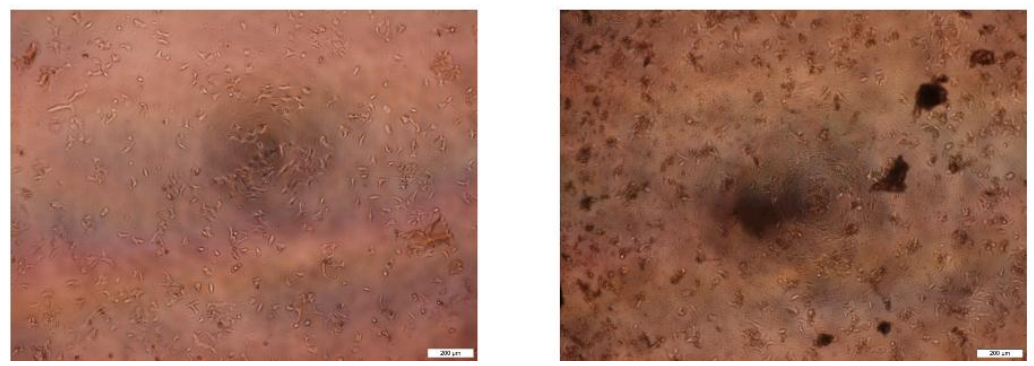

Figure 1. MCF-7 cells treated with $100 \mu \mathrm{g} / \mathrm{mL}$ protein containing fig, lemon, olive, and turnip exosomes for $72 \mathrm{~h}$ were photographed by an inverted microscope. 
Fig exosomes-treated cells were nearly identic with the control cells based on their morphology and concentrations. Lemon exosomes-treated cells were exhibited the impaired growth percentage. Therefore, lemon exosomes might promote cellular death mechanisms in MCF-7 cells. Olive exosomes-treated cells were observed to decrease the cellular growth, however, this reduction was not statistically significant. Turnip exosomes-treated cells exerted the most promising results in microscopic examinations. The cell concentration was remarkably reduced in a field of view, suggesting the turnip exosome-mediated growth inhibition of MCF-7 cells.

\section{Cytotoxicity Assessment}

The viabilities of MCF-7 cells treated with fig, lemon, olive, and turnip exosomes were estimated through the neutral red uptake assay. The percentage of viable cells treated with the fig, lemon, olive and turnip exosomes were $99 \%, 48 \%, 87 \%$, and $27 \%$ respectively. These results imply the anticancer activities of lemon and turnip exosomes.

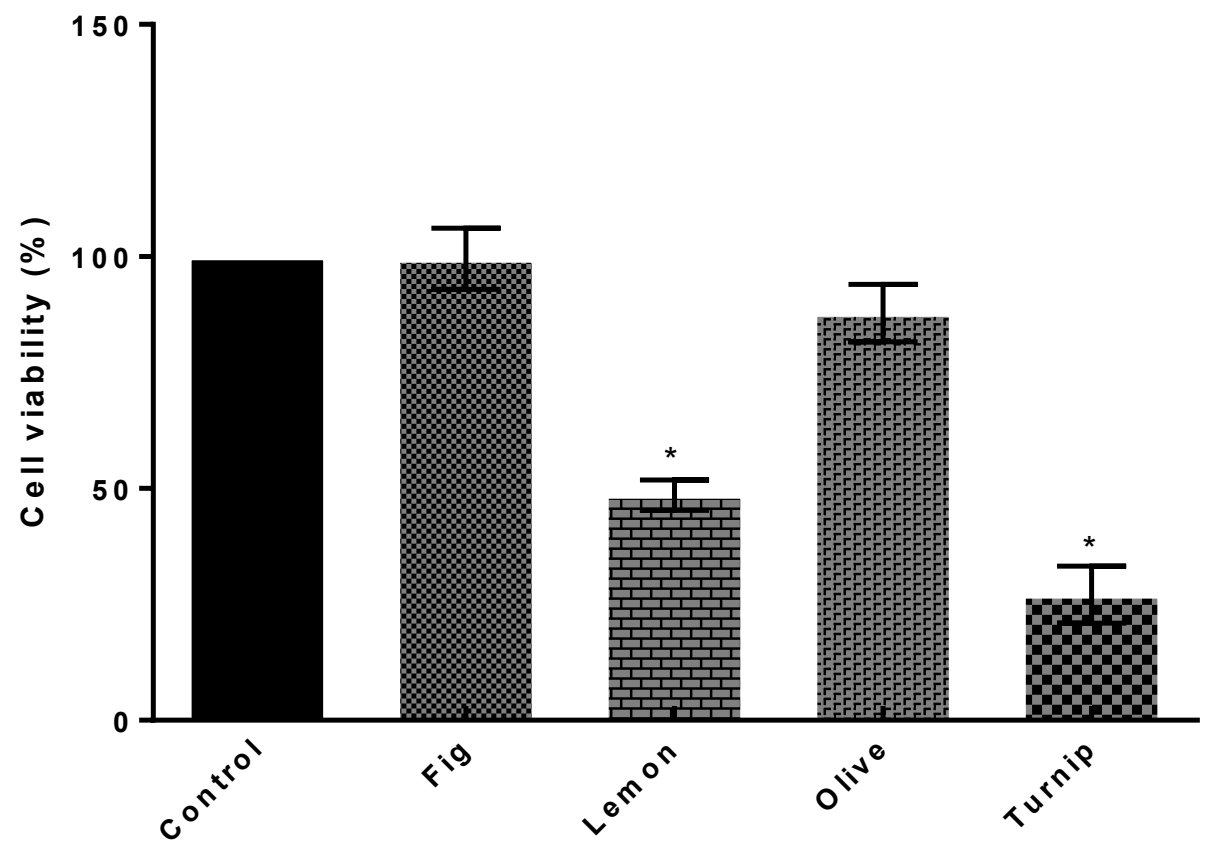

Figure 2. The viabilities of MCF-7 cells treated with $100 \mu \mathrm{g} / \mathrm{mL}$ protein containing fig, lemon, olive and turnip exosomes for $72 \mathrm{~h}$. Statistical comparisons were performed with ANOVA followed by Dunnet's post hoc $(* \mathrm{*}<0.05)$.

As is seen from Table 1, the $\mathrm{IC}_{50}$ values of lemon and turnip exosomes were estimated to be 98.03 and 61.15 $\mu \mathrm{g} / \mathrm{mL}$. However, fig and olive exososmes were not cytotoxic to $100 \mu \mathrm{g} / \mathrm{mL}$.

Table 1. Cytotoxicity of tested exosomes towards MCF7 cells determined by the neutral red assay

\begin{tabular}{|l|c|}
\hline Exosome & IC $_{50}(\mu \mathrm{g} / \mathrm{mL}$ Mean \pm SD $)$ \\
\hline Fig & $>100$ \\
\hline Lemon & $98.03 \pm 13.65$ \\
\hline Olive & $>100$ \\
\hline Turnip & $61.16 \pm 5,63$ \\
\hline
\end{tabular}

\section{DISCUSSION}

The present study is conducted to screen the possible anticancer activities of edible plant derived exosomes from fig, lemon, olive, and turnip. It was demonstrated that while fig and olive exosomes have not any growth inhibitory activities, lemon and turnip exosomes were significantly inhibited the breast cancer proliferation. This observation may be related with the differences of the constituents of exosomes originated from different plants. While some exosomes originated from a particular plant like turnip and lemon can contain nucleic acids, and proteins that have tumor suppressor effects, others such as fig and olive may not. In the literature, lemon exosome-mediated inhibition of the proliferation of leukemia, colorectal adenocarcinoma, and lung carcinoma cell lines are reported (Raimondo et al., 2015). However, this is the first publication to demonstrate the better cytotoxic activities of turnip exosomes than lemon exosomes on a breast cancer cell line.

Lemons are a member of evergreen trees, originated from India, cultivating for more than 4000 years. Polymethoxyflavones enriched in lemons have been well known to exhibit anticancer activities (L. Wang et al., 2014). Moreover, Citrus limon-derived exosomes 
are proven to inhibit cancer cell proliferation and suppress chronic myeloid leukemia xenograft growth by inducing TRAIL-mediated cell death (Raimondo et al., 2015). In this study, it was concordantly realised that the lemon exosomes have inhibitory effects on the proliferation of breast cancer cells.

Turnips are a member of cruciferous vegetables, grown in cool climates, and they have been planted from the Roman times. Organosulphur compounds found in the turnip have been shown to decrease the proliferation of cancer cells (Farag and Motaal, 2010). In addition, broccoli-derived exosomes observed to inhibit mouse colitis (Deng et al., 2017). In this study, the observation that $100 \mu \mathrm{g} / \mathrm{mL}$ protein containing turnip exosomemediated inhibition of the proliferation of a breast cancer cell is unique for exosome-mediated growth inhibition of cancer cells, therefore this is an important contribution to the anticancer activities of cruciferous vegetables.

Despite the absence of data regarding to the cytotoxic effects of turnip exosomes on primary normal cells, this study can initiate new investigations for future studies that are deciphering the mechanism of cell death promoted by turnip exosomes. Besides, since adverse drug reactions are one of the most challenging obstacles in cancer treatment, turnip derived exosomes can be engineered for developing a new drug and/or drug delivery vehicle which has minimum side effects with the edible character of turnip.

\section{REFERENCES}

An Q, Huckelhoven R, Kogel K-H, van Bel AJE 2006. Multivesicular bodies participate in a cell wallassociated defence response in barley leaves attacked by the pathogenic powdery mildew fungus. Cellular Microbiology, 8(6): 1009-1019.

Böhlenius H, Mørch SM, Godfrey D, Nielsen ME, Thordal-Christensen H 2010. The Multivesicular Body-Localized GTPase ARFA1b/1c Is Important for Callose Deposition and ROR2 SyntaxinDependent Preinvasive Basal Defense in Barley. The Plant Cell, 22(11): 3831-3844.

Boriachek K, Islam MN, Möller A, Salomon C, Nguyen N-T, Hossain MSA, Yamauchi Y, Shiddiky MJA 2018. Biological Functions and Current Advances in Isolation and Detection Strategies for Exosome Nanovesicles. Small, 14(6): 1702153. https://doi.org/ 10.1002/smll.201702153

Deatherage BL, Cookson BT 2012. Membrane Vesicle Release in Bacteria, Eukaryotes, and Archaea: a Conserved yet Underappreciated Aspect of Microbial Life. Infection and Immunity, 80(6): 1948-1957.

Deng Z, Rong Y, Teng Y, Mu J, Zhuang X, Tseng M, Samykutty A, Zhang L, Yan J, Miller D, Suttles J, Zhang H-G 2017. Broccoli-Derived Nanoparticle Inhibits Mouse Colitis by Activating Dendritic Cell
AMP-Activated Protein Kinase. Molecular Therapy, 25(7): 1641-1654.

Dragomir M, Chen B, Calin GA 2018. Exosomal lncRNAs as new players in cell-to-cell communication. Translational Cancer Research, 7(S2): S243-S252. https://doi.org/10.21037/ tcr.2017.10.46

Escudier B, Dorval T, Chaput N, André F, Caby M-P, Novault S, Flament C, Leboulaire C, Borg C, Amigorena S, Boccaccio C, Bonnerot C, Dhellin O, Movassagh M, Piperno S, Robert C, Serra V, Valente N, Le Pecq J-B, Spatz A, Lantz O, Tursz T, Angevin E, Zitvogel L 2005. Vaccination of metastatic melanoma patients with autologous dendritic cell (DC) derived-exosomes: results of thefirst phase I clinical trial. Journal of Translational Medicine, 3(1): 10.

Farag MA, Motaal AAA 2010. Sulforaphane composition, cytotoxic and antioxidant activity of crucifer vegetables. Journal of Advanced Research, 1(1): $65-70$.

Hoshino A, Costa-Silva B, Shen T-L, Rodrigues G, Hashimoto A, Tesic Mark M, Molina H, Kohsaka S, Di Giannatale A, Ceder S, Singh S, Williams C, Soplop N, Uryu K, Pharmer L, King T, Bojmar L, Davies AE, Ararso Y, Zhang T, Zhang H, Hernandez J, Weiss JM, Dumont-Cole VD, Kramer K, Wexler LH, Narendran A, Schwartz GK, Healey JH, Sandstrom P, Jørgen Labori K, Kure EH, Grandgenett PM, Hollingsworth MA, de Sousa M, Kaur S, Jain M, Mallya K, Batra SK, Jarnagin WR, Brady MS, Fodstad O, Muller V, Pantel K, Minn AJ, Bissell MJ, Garcia BA, Kang Y, Rajasekhar VK, Ghajar CM, Matei I, Peinado H, Bromberg J, Lyden D 2015. Tumour exosome integrins determine organotropic metastasis. Nature, 527(7578): 329335. https://doi.org/10.1038/nature15756

Karaosmanoğlu O, Banerjee S, Sivas H 2018. Identification of biomarkers associated with partial epithelial to mesenchymal transition in the secretome of slug over-expressing hepatocellular carcinoma cells. Cellular Oncology, 41(4): 439-453. https://doi.org/10.1007/s13402-018-0384-6

Kibria G, Ramos EK, Wan Y, Gius DR, Liu H 2018. Exosomes as a Drug Delivery System in Cancer Therapy: Potential and Challenges. Molecular Pharmaceutics, 15(9): 3625-3633.

Li X-B, Zhang Z-R, Schluesener HJ, Xu S-Q 2006. Role of exosomes in immune regulation. Journal of Cellular and Molecular Medicine, 10(2): 364-375. https://doi.org/10.1111/j.1582-4934.2006.tb00405.x

Ma Q-L, Teng E, Zuo X, Jones M, Teter B, Zhao EY, Zhu C, Bilousova T, Gylys KH, Apostolova LG, LaDu MJ, Hossain MA, Frautschy SA, Cole GM 2018. Neuronal pentraxin 1: A synaptic-derived plasma biomarker in Alzheimer's disease. Neurobiology of Disease, 114: 120-128. https://doi.org/10.1016/j.nbd.2018.02.014 
Meyer D, Pajonk S, Micali C, O'Connell R, SchulzeLefert P 2009. Extracellular transport and integration of plant secretory proteins into pathogen-induced cell wall compartments. The Plant Journal, 57(6): 986-999.

Min H, Sun X, Yang X, Zhu H, Liu J, Wang Y, Chen G, Sun X 2018. Exosomes Derived from Irradiated Esophageal Carcinoma-Infiltrating T Cells Promote Metastasis by Inducing the EpithelialMesenchymal Transition in Esophageal Cancer Cells. Pathology \& Oncology Research, 24(1): 1118. https://doi.org/10.1007/s12253-016-0185-z

Mincheva-Nilsson L, Baranov V 2010. The Role of Placental Exosomes in Reproduction. American Journal of Reproductive Immunology, 63(6): 520533.

Mineo M, Garfield SH, Taverna S, Flugy A, De Leo G, Alessandro R, Kohn EC 2012. Exosomes released by K562 chronic myeloid leukemia cells promote angiogenesis in a src-dependent fashion. Angiogenesis, 15(1): 33-45.

Mu J, Zhuang X, Wang Q, Jiang H, Deng Z, Wang B, Zhang L, Kakar S, Jun Y, Miller D, Zhang H 2014. Interspecies communication between plant and mouse gut host cells through edible plant derived exosome-like nanoparticles. Molecular Nutrition \& Food Research, 58(7): 1561-1573.

Nagarajah S 2016. Exosome Secretion - More Than Simple Waste Disposal? Implications for Physiology, Diagnostics and Therapeutics. Journal of circulating biomarkers, 5: 7. https://doi.org/ $10.5772 / 62975$

Pant S, Hilton H, Burczynski ME 2012. The multifaceted exosome: Biogenesis, role in normal and aberrant cellular function, and frontiers for pharmacological and biomarker opportunities. Biochemical Pharmacology, 83(11): 1484-1494.

Raimondo S, Naselli F, Fontana S, Monteleone F, Lo Dico A, Saieva L, Zito G, Flugy A, Manno M, Di Bella MA, De Leo G, Alessandro R 2015. Citrus limon-derived nanovesicles inhibit cancer cell proliferation and suppress CML xenograft growth by inducing TRAIL-mediated cell death. Oncotarget, 6(23): 19514-27. https://doi.org/ 10.18632/oncotarget.4004

Schorey JS, Bhatnagar S 2008. Exosome Function: From Tumor Immunology to Pathogen Biology.
Traffic, 9(6): 871-881.

Théry C, Amigorena S, Raposo G, Clayton A 2006. Isolation and Characterization of Exosomes from Cell Culture Supernatants and Biological Fluids. Current Protocols in Cell Biology, 30(1): 3.22.13.22.29.

https://doi.org/10.1002/0471143030.cb0322s30

Van Niel G, D'Angelo G, Raposo G 2018. Shedding light on the cell biology of extracellular vesicles. Nature Reviews Molecular Cell Biology, 19(4): 213228. https://doi.org/10.1038/nrm.2017.125

Wang B, Zhuang X, Deng Z-B, Jiang H, Mu J, Wang Q, Xiang X, Guo H, Zhang L, Dryden G, Yan J, Miller D, Zhang H-G 2014. Targeted Drug Delivery to Intestinal Macrophages by Bioactive Nanovesicles Released from Grapefruit. Molecular Therapy, 22(3): 522-534. https://doi.org/10.1038/mt.2013.190

Wang L, Wang J, Fang L, Zheng Z, Zhi D, Wang S, Li S, Ho C-T, Zhao H 2014. Anticancer activities of citrus peel polymethoxyflavones related to angiogenesis and others. Biomed Research International, 2014: 453972. https://doi.org/ $10.1155 / 2014 / 453972$

Wang Q, Ren Y, Mu J, Egilmez NK, Zhuang X, Deng Z, Zhang L, Yan J, Miller D, Zhang H-G 2015. Grapefruit-Derived Nanovectors Use an Activated Leukocyte Trafficking Pathway to Deliver Therapeutic Agents to Inflammatory Tumor Sites. Cancer Research, 75(12): 2520-2529.

Xiao J, Feng S, Wang X, Long K, Luo Y, Wang Y, Ma J, Tang Q, Jin L, Li X, Li M 2018. Identification of exosome-like nanoparticle-derived microRNAs from 11 edible fruits and vegetables. PeerJ, 6: e5186. https://doi.org/10.7717/peerj.5186

Xin H, Li Y, Cui Y, Yang JJ, Zhang ZG, Chopp M 2013. Systemic Administration of Exosomes Released from Mesenchymal Stromal Cells Promote Functional Recovery and Neurovascular Plasticity After Stroke in Rats. J. Cereb. Journal of Cerebral Blood Flow \& Metababolism, 33(11): 1711-1715.

Zhuang X, Deng Z-B, Mu J, Zhang L, Yan J, Miller D, Feng W, McClain CJ, Zhang H-G 2015. Gingerderived nanoparticles protect against alcoholinduced liver damage. Journal of Extracellular Vesicles, 4(1): 28713. https://doi.org/10.3402/ jev.v4.28713 